\title{
TIBETAANS-BOEDDHISTISCHE BEELDHOUWKUNST EEN SELECTIE UIT EEN PRIVE-VERZAMELING
}

Een van de interessante aspecten van verzamelen is dat elke verzamelaar zijn of haar eigen niche kan vinden. En zo kan men op de gekste plekken de meest verrassende collecties aantreffen, die vaak nog nooit door de buitenwereld gezien, laat staan gepubliceerd zijn.

Zo ook de objecten die de hoofdrol spelen in dit artikel: zij zijn afkomstig uit een particuliere Nederlandse collectie die als hoofdthema Aziatische sculptuur heeft. Voor dit artikel hebben wij uit deze collectie een aantal Tibetaanse sculpturen geselecteerd, voornamelijk op kwaliteit, maar ook op inhoud. Want dat is juist zo leuk: we kunnen perfecte, kwalitatief hoogstaande objecten bewonderen om hun merites, maar wetenschappelijk kunnen juist de wat meer onooglijke objecten een geweldig verhaal opleveren om hun inhoud, symboliek, of ritueel gebruik.

Tibetaanse kunst - het moet me toch weer eens van het hart - kent helaas, en onbegrijpelijk, te weinig liefhebbers in de lage landen. De kunst van het Himalaya-gebied is altijd enigszins behandeld als een stiefkindje. Volstrekt ten onrechte! De Tibetaans-boeddhistische cultuur is buitengewoon gevarieerd, subtiel en diepgaand en verdient daarom beter.

Toen het boeddhisme in de $10^{\mathrm{e}}-11^{\mathrm{e}}$ eeuw voor de tweede maal, en toen definitief, in Tibet werd geïntroduceerd, kwam de religieuze en culturele invloed voornamelijk vanuit het zuiden, het toen nog boeddhistische India. Door de toenemende dreiging en verwoestingen door de moslim-legers, die vanuit het westen India binnenvielen, weken veel monniken van de grote boeddhistische centra in het noordoosten van India uit naar het noorden: eerst naar Nepal, en later ook naar de andere kant van de Himalayabergketen, naar de Tibetaanse hoogvlakte, waar zich juist in deze tijd een aarzelende revival van deze godsdienst aandiende. Deze puur-Indiase stilistische invloeden zijn goed te zien in twee vroege (onvergulde) bronzen beelden van de boeddha Sakyamuni, de 'stichter' van het boeddhisme (afb. 1). Het kleinere beeld is het oudst: $12^{\mathrm{e}}-13^{\mathrm{e}}$ eeuw. Een trots lichaam, het monniksgewaad wordt heel summier aangegeven en de boeddha heeft een mooi meditatief gelaat met een typische V-vormige mond. Dit is een voor die tijd universele stijl, die van India naar Nepal en verder naar Tibet, Birma en naar Zuidoost-Azië is uitgewaaierd. Het grotere beeld dateert van de $13^{\mathrm{e}}$ of begin $14^{\mathrm{e}}$ eeuw. Opvallend zijn de brede lotusbladeren van de troon, een vriendelijk, vol gezicht en een in onze ogen overdreven grote urna (uitstulping van de schedel). Een leuk detail vormen de twee minuscule leeuwtjes die links en rechts boven de lotustroon zijn afgebeeld; eigenlijk zijn zij bedoeld om de gehele troon te dragen. Op zich zijn ook hier de vormgeving van de troon, het lichaam en het monniksgewaad geheel terug te voeren op de Indiase Pala-stijl. 


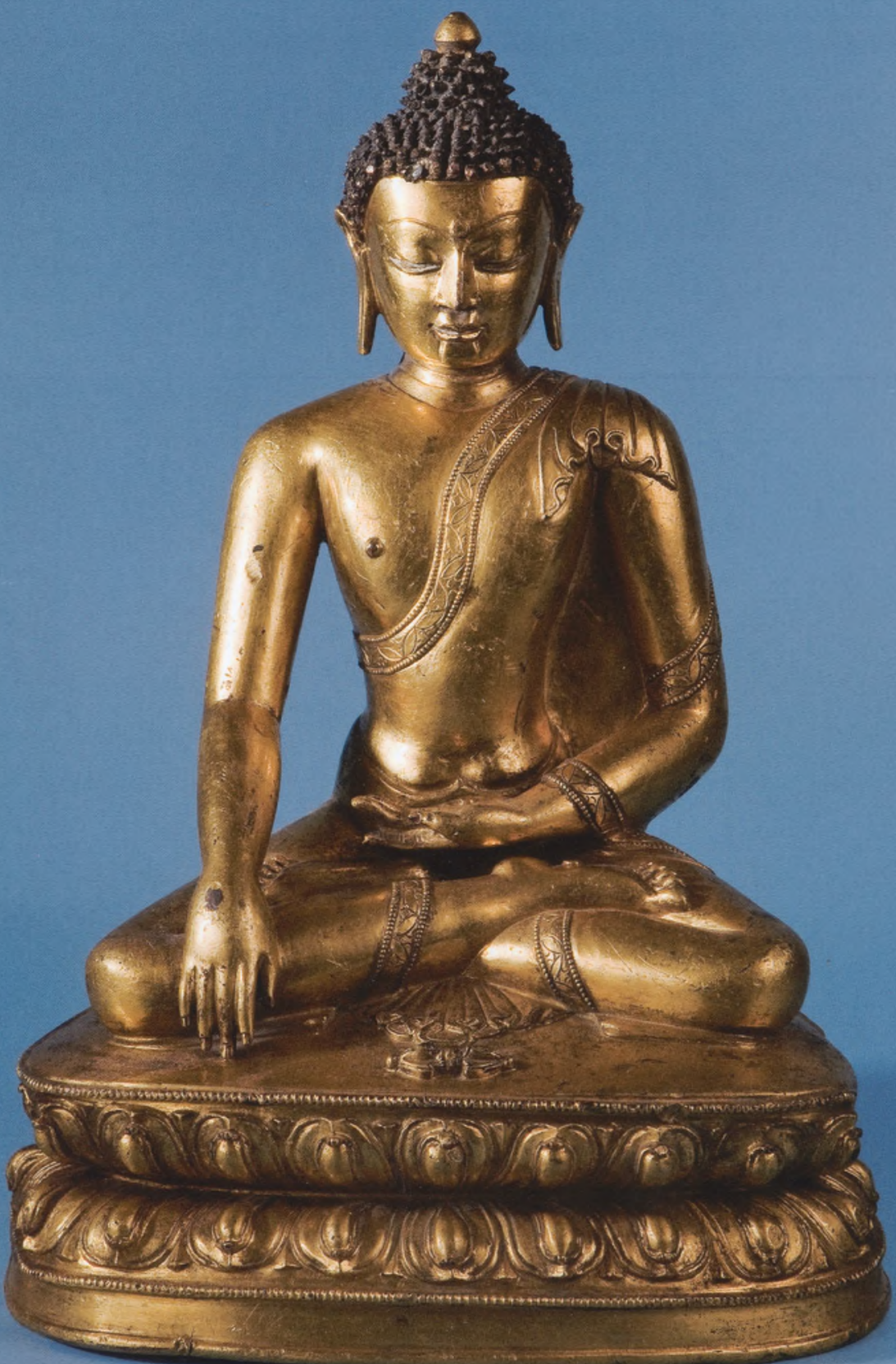

Afb. 2. Boeddha

Sakyamuni, vuurverguld brons, h. $30 \mathrm{~cm}$., Tibet, $14^{e}-15^{e}$ eeuw. 


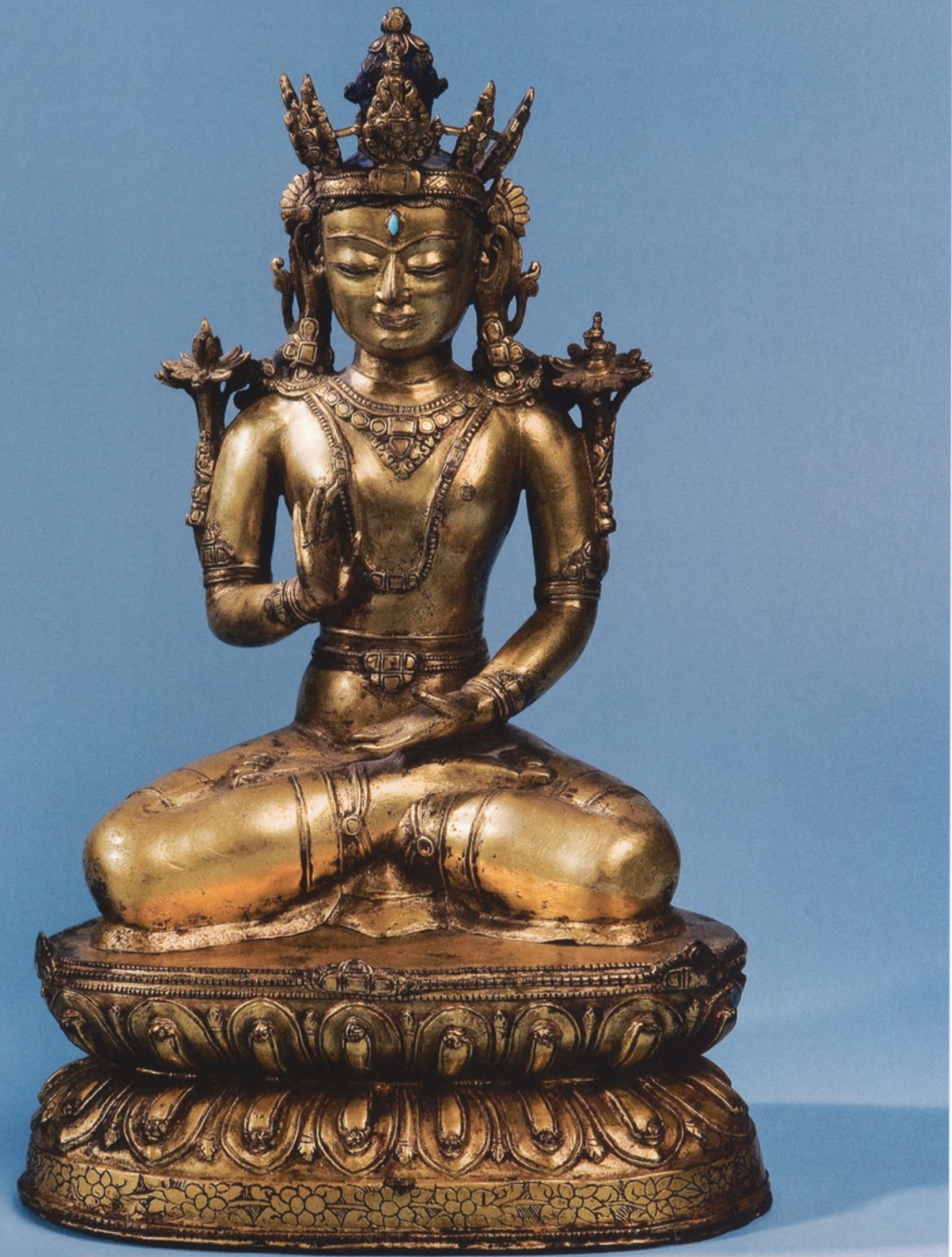

\section{Afb. 3. Boeddha}




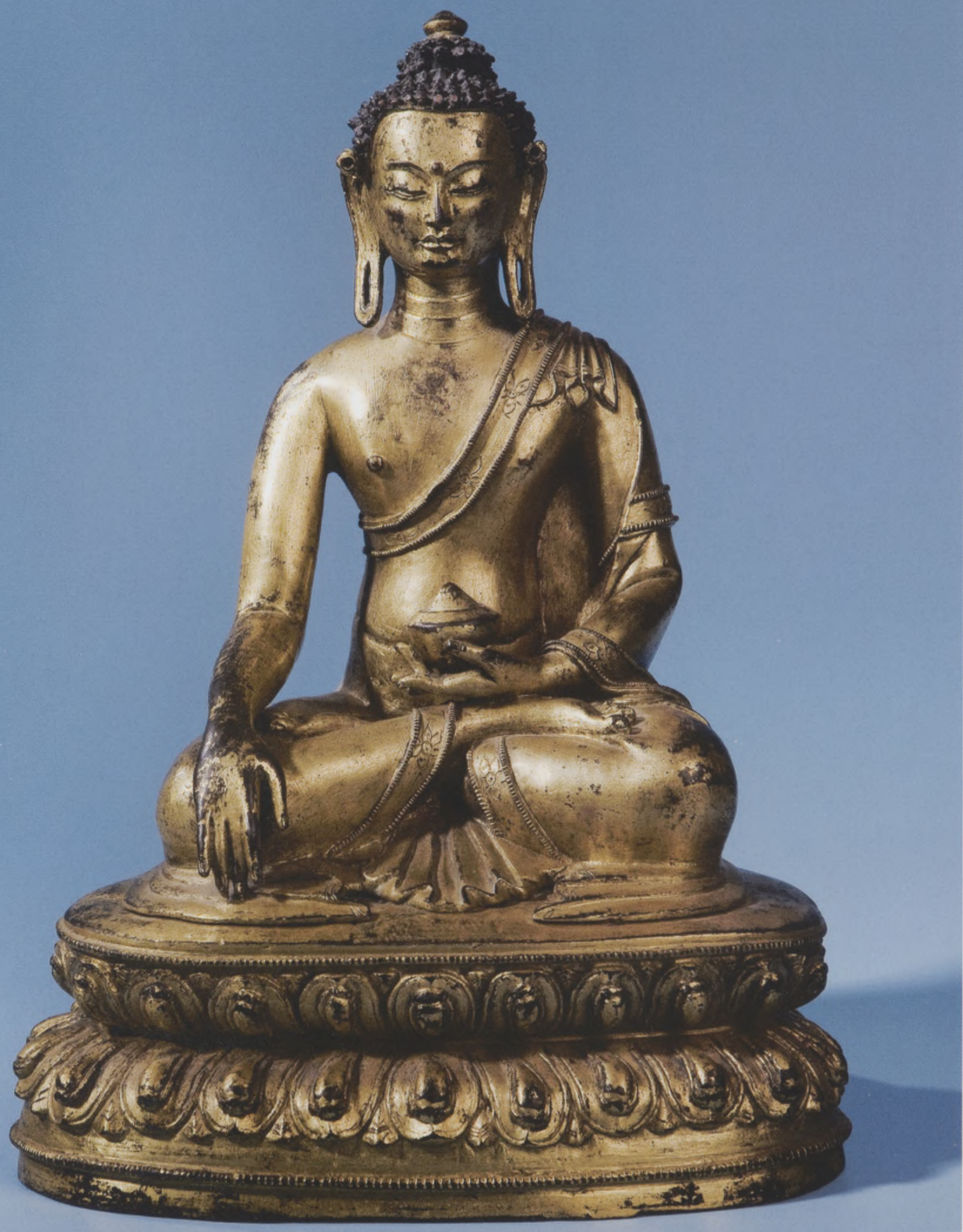

Afb. 4. Boeddha

Maitreya, vuurverguld brons, ingelegd met een turkoois, h. $31,5 \mathrm{~cm}$., Tibet, $15^{e}$ eeuw. 
Twee vuurvergulde bronzen van de boeddha Sakyamuni (afb. 2, 3) lijken ogenschijnlijk veel op elkaar. Beide dateren uit de $14^{\mathrm{e}}$ of het begin van de $15^{e}$ eeuw, en zijn ongeveer even groot. Toch, als men goed kijkt, blijken zij geheel verschillend te zijn: de uitdrukking van de gezichten (de boeddha van afbeelding 2 in diepe meditatie en devoot, die van afbeelding 3 trots en streng), de lichaamsbouw, en de opbouw van de lotustronen maken dat het om individuele afbeeldingen van de historische boeddha gaat. Dit is een mooi voorbeeld voor de velen die menen dat de Tibetaanse kunst eigenlijk alleen maar veel van hetzelfde is. De ogen van deze beelden lijken 'leeg', maar u moet zich voorstellen dat de gezichten oorspronkelijk op rituele wijze beschilderd werden, en bij het schilderen van de ogen pas 'levend' gemaakt werden. De eerste van deze twee boeddha's heeft voor zich op de lotustroon een vajra liggen. Lang heeft men op basis van een dergelijke vajra zo'n boeddha bestempeld als de tathagata Akshobhya, de esoterische tegenhanger van de 'aardse' Sakyamuni, die inderdaad als symbool de vajra heeft. $\mathrm{Nu}$ is men langzamerhand tot de overtuiging gekomen dat ook een boeddha met een dergelijke vajra de boeddha Sakyamuni moet zijn: het gaat hier om het uitbeelden van de vajra-troon; de boeddha Akshobhya houdt zijn attribuut meestal staand in zijn linkerhand vast. Een mooi detail van de boeddha in afbeelding 3 zijn de twee kleine bloemetjes boven zijn oren.

Het Tibetaans boeddhisme is een esoterische verdieping van het Mahayanaboeddhisme. In de loop van de eeuwen heeft zich een gigantisch complex van boeddha's, boddhisattva's, en beschermgodheden ontwikkeld, die alle binnen de godsdienst een bepaalde plek en functie hebben. Zo wordt de boeddha Sakyamuni beschouwd als de boeddha van onze tijd (kalpa). Als deze periode voltooid is, zal er nog een tijdperk volgen, waar Maitreya, de boeddha van de toekomst zal resideren. Deze boeddha is te herkennen aan zijn handhouding, in combinatie met - in dit geval - een vaasje (afb. 4). Behalve historische, aardse boeddha's kent men in het Mahayana-boeddhisme ook een groep van transcendente, meditatieve boeddha's, de vijf tathagata's, die elk voor een van de vijf richtingen (vier plus het centrum), vijf elementen, kleuren en handhoudingen staan. Elk van deze boeddha's heeft weer een complete 'familie' van bodhisattva's en afgeleide godheden bij zich. Als dan ook nog eens elke kloostertraditie in Tibet aparte variaties van bepaalde godheden er op na kan hebben, begrijpt $u$ dat wij bij het identificeren van al deze godheden gedwongen zijn gebruik te maken van iconografische determineerboeken: de Jac.P. Thijssens van het Tibetaans boeddhisme. Het zijn er simpelweg te veel!

Een belangrijke en populaire tathagata is Amitayus, de boeddha van het lange leven (afb. 5, links), die te herkennen is aan zijn handhouding (meditatie-houding) en het lang-leven-vaasje, dat hij vasthoudt. Dit brons is niet vuurverguld, maar lakverguld: het brons is eerst voorzien van een donker laklaagje, dat vervolgens van verguldsel is voorzien. Dit is een Chinese techniek en dit brons is dan ook niet in Tibet, maar in China vervaardigd. Gedurende verschillende periodes in de Chinese culturele geschiedenis heeft het Tibetaans boeddhisme een grote invloed gekend en veel sculpturen, die wij aanvankelijk als Tibetaans met Chinese invloed zouden hebben beschouwd, blijken puur Chinees te zijn en bedoeld voor Chinese boeddhistische tempels, die van Tibetaanse traditie waren. Dit beeld, daterend uit de late Mingdynastie ( $17^{\mathrm{e}}$ eeuw), laat vooral Nepalese/stijlkenmerken zien die zowel in de Yuan-als in de Ming-dynastie de Chinees-boeddhistische kunst hebben ${ }^{\text {ree }}$ access 


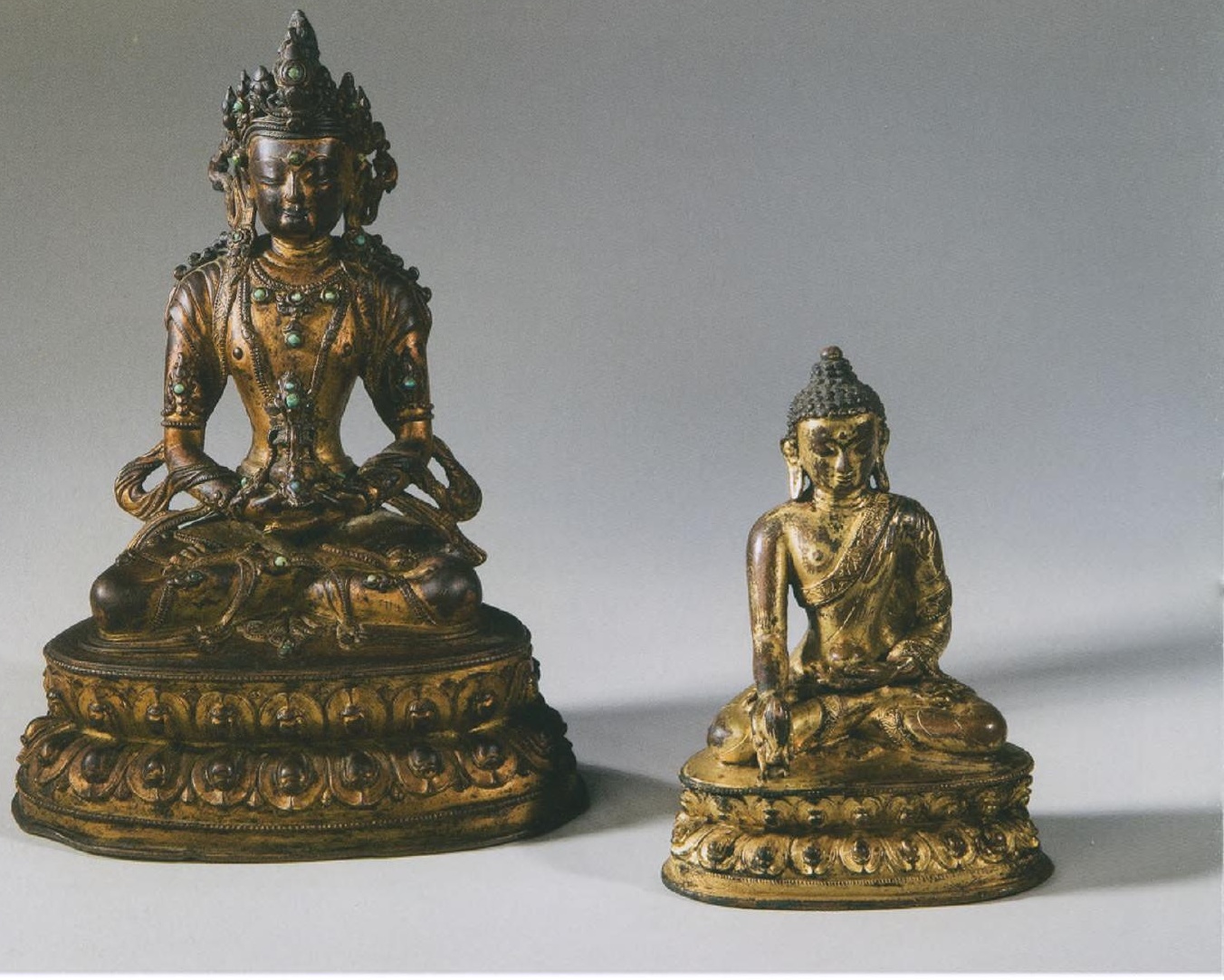

Afb. 5 .

(links) Boeddha Amitayus, lakverguld brons, ingelegd met turkooizen, China, 17 eeuw. (rechts) Boeddha Baishajyaguru, vuurverguld brons, Tibet, $16^{\circ}$ eeuw. bepaald. In dezelfde tijd werden natuurlijk ook beelden vervaardigd voor boeddhistische tempels in China, die geen relatie met Tibet hadden en dan een compleet andere, puur-Chinese stijl tonen.

Behalve de groep van de vijf tathagata's kwamen er oneindig veel meer boeddha's in het pantheon, alle met hun specifieke kenmerken en functies. Een belangrijke en begrijpelijkerwijs populaire groep is die van de medicinale boeddha's, aangevoerd door Baishajyaguru, die in deze collectie vertegenwoordigd is met een klein verguld bronsje (afb. 5, rechts). Deze boeddha is altijd te herkennen aan zijn handhouding en belangrijkste attribuut: zijn rechterhand houdt hij met de palm naar buiten, de houding die het geven symboliseert, namelijk het geven van genezing. Bovendien houdt hij in deze hand een geneeskrachtige vrucht vast.

Als we het bronsje links in afbeelding 6 zien, zullen we in eerste instantie denken hier met een monnik te maken te hebben. Gezien de markante muts ligt een vergelijking voor de hand met de beroemde tantrische meester Padmasambhava, die in de $8^{\mathrm{e}}$ eeuw de esoterische variant van het Mahayana-boeddhisme in Tibet introduceerde. Maar niets is minder waar. Aan de hand van twee publicaties over drie nagenoeg identieke beeldjes weten we dat het hier gaat om een merkwaardige versie van dezelfde medicinale boeddha. ${ }^{1}$ Ook zien wij dat hij zijn rechterhand met de palm naar voren houdt, met daarin de medicinale vrucht. Kwalitatief gezien is dit een 


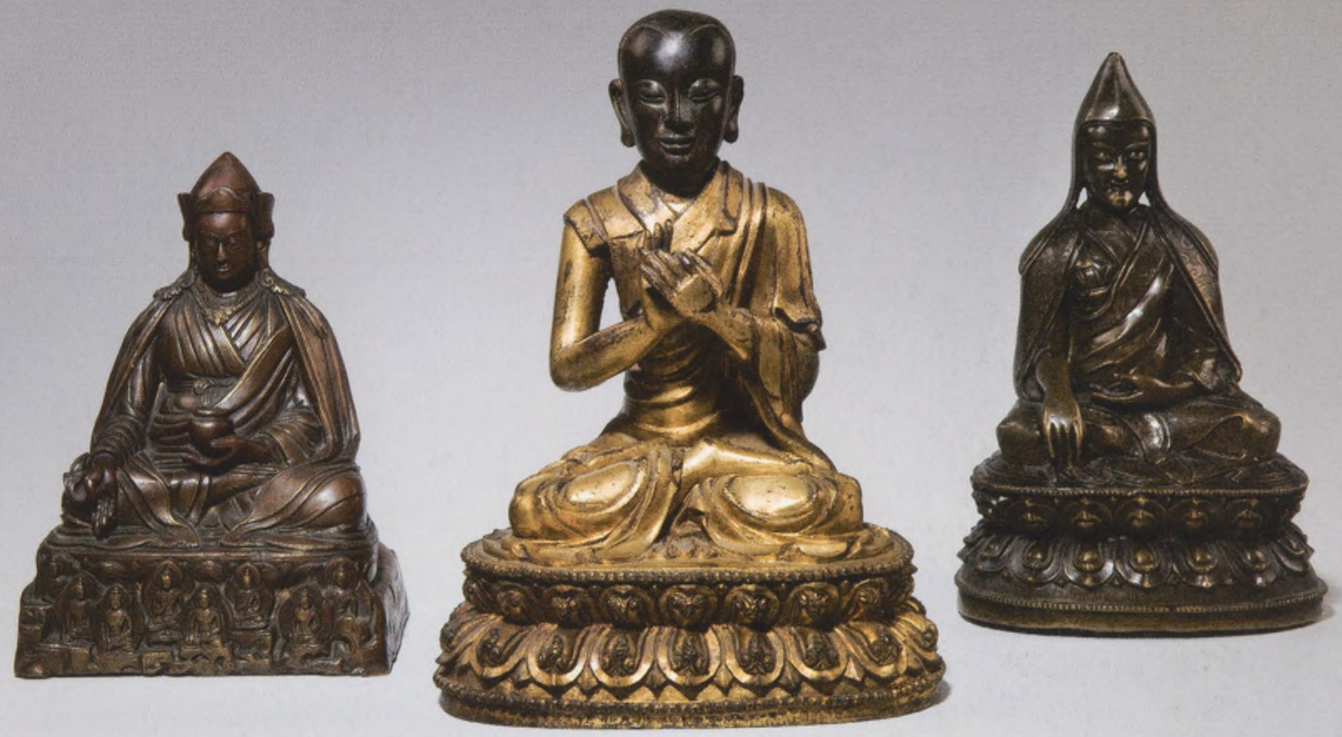

Afb. 6.

(links) Boeddha Baishajyaguru als monnik, koper, h. $16 \mathrm{~cm}$., Tibet, $19^{e}$ eeuw. (midden) portret van een monnik (Tsongkhapa?), vuurverguld koper, h. $21 \mathrm{~cm}$., China, gedateerd 1514. (rechts) portret van een monnik, brons, h. $18 \mathrm{~cm}$., Tibet, $16^{e}$ eeuw. van de mindere objecten in de verzameling, maar aan de andere kant is het juist een van de boeiendste. Aan de achterzijde van het beeldje is een Tibetaanse tekst, die een aanroeping is aan Baishajyaguru, met de wens de mensheid te bevrijden van alle mogelijke vreselijke ziekten. Dit bronsje stelt dus de medicinale boeddha voor, maar dan, heel bijzonder, in zijn incarnatie als monnik. Al met al ken ik zeven van deze, bijna identieke beeldjes. $\mathrm{Zij}$ dateren alle uit de $19^{\mathrm{e}}$ eeuw, zijn heel dun gegoten en op het eerste gezicht lijken ze uit een mal te zijn vervaardigd. Toch blijken ook deze beeldjes volgens de verloren-wasmethode te zijn gegoten; ze zijn alle iets anders van formaat en de tekst aan de achterzijde is een stempelafdruk in de was. Aan de voorzijde van de troon zijn de acht verschillende boeddha's te zien, die samen met Baishajyaguru een groep vormen.

Het kloosterleven speelt in het Tibetaans boeddhisme een uiterst belangrijke rol. De kloosters, soms van gigantische afmetingen met vele duizenden monniken, zijn van oudsher de centra geweest van religie, cultuur, kennis, maar ook van de economie en dus de macht. In de verschillende kloostertradities kent men heilige reïncarnaties (tulku), van wie de Dalai Lama voor ons natuurlijk de bekendste is. Deze heiligverklaarde monniken werden ook afgebeeld, vaak voor een ritueel, vlak na hun dood. In sommige gevallen gaat het om een uit herinneringogemaakt portret, datnheeb realistiseh: $46 \mathrm{Am}$ kan zijn, compleet met rimpels, pukkels, uitstekende tanden, enzovbort. ${ }^{\text {free access }}$ 


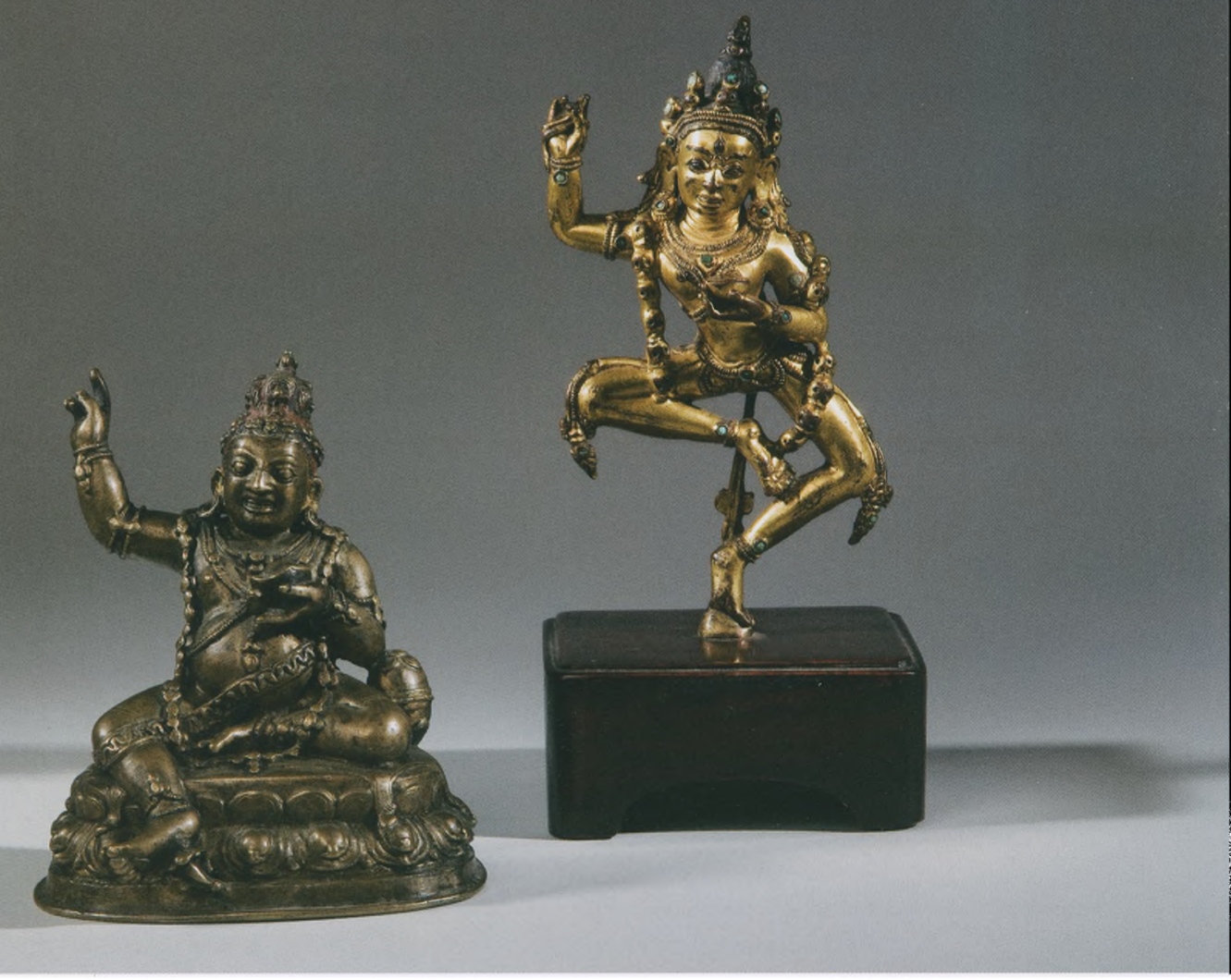

Afb. 7.

(links) Mahasiddha

Virupa, brons, h. $12 \mathrm{~cm}$.,

Tibet, $15^{e}$ eeuw.

(rechts) Dakini, vuurverguld brons,

h. $13,5 \mathrm{~cm}$., Tibet, $16^{\text {e eeuw. }}$
Afbeelding 6 (rechts) toont een dergelijk portret, zeer waarschijnlijk van een monnik die behoorde tot de Sakya-traditie: een vriendelijke man, in rijk uitgevoerde monniksmantel en met een muts op het hoofd. In andere gevallen wordt zo'n portret geïdealiseerd, zodat we te maken hebben met een stereotiep gezicht (afb. 6, midden). Dit Chinese beeld wordt door een inscriptie aan de voorzijde van de sokkel gedateerd in 1514, in de regeringsperiode van de Ming-keizer Zhengde (r. 1505-1521). ${ }^{2}$ De handen zijn in dharmachakra-mudra voor de borst, en dit beeld zou een afbeelding kunnen zijn van Tsongkhapa, de stichter van de Gelugpa ('Geelkap')-traditie (13571419). Het was juist de Gelugpa-kloostertraditie, die vanaf de $15^{\mathrm{e}}$ eeuw veel invloed en aanzien kreeg in China, vooral aan het keizelijke hof in Beijing. Hij droeg zeer waarschijnlijk een gele textielen monniksmuts.

Een andere groep van historische personages die geregeld afgebeeld werd, is die van de Mahasiddha's, een groep van 84 veelal Indiase meesters, die de basis hebben gevormd van het tantrisch, esoterische boeddhisme, zoals dat in de eerste eeuwen na het begin van onze jaartelling ontwikkeld is. Deze zogenoemde siddha's zijn vooral in Tibet bijzonder populair geworden, niet in de laatste plaats door hun - op zijn zachtst uitgedrukt - aparte levenswijze. $Z$ ij kwamen uit alle verschillende lagen van de bevolking, van steenrijk en van adel, tot arm en behorend tot de laagste kaste. Veel siddha's hebben het Goddelijke Inzicht verkregen tijdens hun leven door hun liederlijke en 
asociale gedrag. Dat is een aspect van de Tibetaanse cultuur, dat ik zo waardeer: hoe menselijker en met hoe meer fouten, des te geliefder kan een heilige voor de Tibetanen worden; hij is een van hen.

Een prachtig voorbeeld is een episode uit het leven van de siddha Virupa, die hier afgebeeld is op afbeelding 7 (links), met zijn karakteristieke opgestoken rechterarm. Hij stond namelijk bekend door zijn mateloze drinkgelagen.

Zo zat hij eens in een kroeg en na het zoveelste glas vroeg de bezorgde waard hem de rekening te betalen, waarop Virupa antwoordde dat hij dat zou doen, als de schaduw een bepaald punt bereikt zou hebben. Tegelijkertijd hield hij met zijn tantrische krachten de zon tegen, zodat hij nog vele dagen kon doordrinken. ${ }^{3}$ Let wel, we hebben het hier over een persoon die in de $8^{e}$ eeuw in het noorden van India leefde.

Zoals bij zoveel godsdiensten het geval is, heeft u gemerkt dat ook het Tibetaans boeddhisme een mannenzaak is. Het gaat bijna altijd om mannelijke godheden, de kloosterwereld wordt bepaald door monniken (nonnen bestaan wel, maar zijn geheel onderworpen aan de monniken-wereld). Vrouwelijke godheden bestaan bij de gratie dat zij de tegenpolen van de mannelijke goden zijn. Het Chinese principe yin yang wordt in Tibet yab yum (vader - moeder) genoemd en elke boeddha, bodhisattva of andere godheid heeft een vrouwelijke tegenhangster. Zo bestaat er de groep van de dakini's, vrouwelijke woeste godinnen, die veelal naakt, dansend, en omhangen met guïrlandes van afgehakte hoofden, worden afgebeeld. Deze dames plachten veelal te verblijven op de knekelvelden (de heilige plekken waar overledenen in stukken werden gehakt om gevoerd te worden aan de gieren), om hier hogere, tantrische inzichten te verwerven. In de collectie is een prachtig, verguld bronsje (afb. 7 , rechts), dat bijzonder mooi de essentie van een dakini uitbeeldt. Zij danst op één been, het andere been is opgetrokken, en in haar handen houdt zij een hakmes en een menselijke schedelkap als drinkbeker. $\mathrm{U}$ moet wel bedenken dat dit, net als alles in de Tibetaanse kunst, geheel overdrachtelijk bedoeld is. Dit beeldje geeft symbolisch de tantrische kracht en het vrouwelijke aspect van de godsdienst weer.

Een geheel andere vorm van beeldhouwkunst vinden we bij het laatste object (afb. 8). Het gaat hier om een houten boekdeksel, waarvan de buitenzijde buitengewoon verfijnd van snijwerk is voorzien. Tibetaanse boeken waren voornamelijk religieus van aard en werden eigenlijk alleen in kloosters vervaardigd en bewaard. In Tibet waren gigantische bibliotheken van vele tienduizenden boeken, die helaas tijdens de Chinese Culturele Revolutie (1966-1976) voor het overgrote deel volledig verwoest zijn. U moet zich een Tibetaans boek voorstellen als losbladig, met langwerpige vellen. Het pak bladen, het boekblok, werd in een textielen, meestal zijden doek verpakt en kreeg onder en boven twee houten planken ter bescherming. Omdat het geschreven woord, de bron van kennis en overdracht, bij uitstek vereerd en gerespecteerd werd, waren deze beschermplanken vaak buitengewoon fraai versierd, zoals in dit geval met uitbundig snijwerk. Ook het gebruik van hout voor deze bescherming is in een land, waar hout zeer spaarzaam voorkomt, een teken aan de wand.

In het midden is de boeddha Sakyamuni afgebeeld, omgeven door een fraai aureool (prabhamandala) en bekroond door een mythische vogel (khyung). De troonzetel wordt hier door twee leeuwtjes gedragen. Links van de boeddha zit de vierarmige Avalokiteshvara (Sadakshari) de specifieke beschermheilige $46 \mathrm{AM}$ van Tibet, en de vorm van Avalokiteshvara waarvan de Dalai Lama ajls freen access 


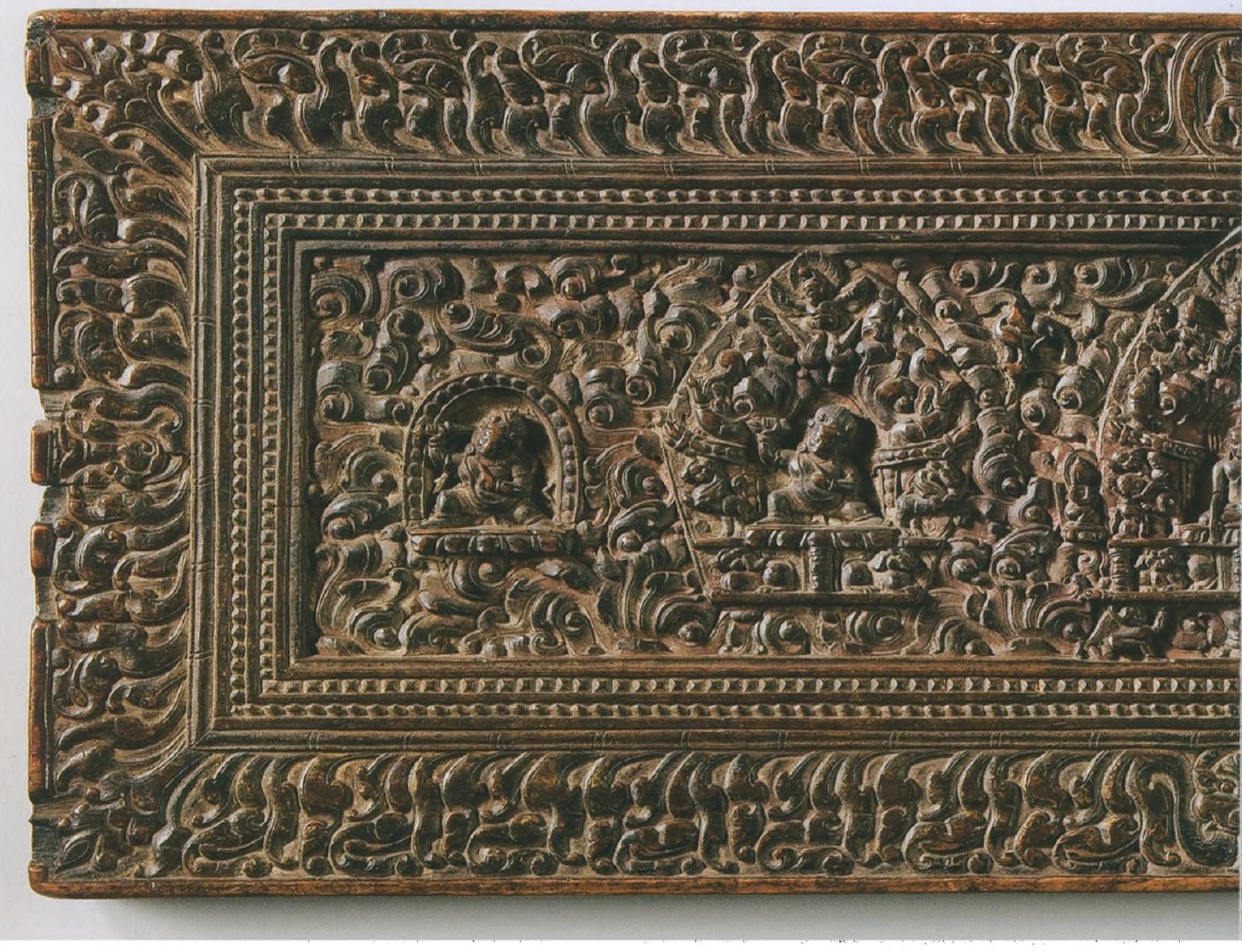

Afb. 8.

Boekdeksel, hout, $71 \times 27 \mathrm{~cm}$., Tibet,

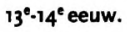

verschijningsvorm op aarde wordt gezien. In het schitterende snijwerk, dat als achtergrond van de verschillende godheden dient, zijn enkele beestjes verborgen. Midden onder zien we een kirtimukha, een monsterkop, die dient als bescherming van het geheel. ${ }^{4}$

In de bovenrand zien we een merkwaardig motief: twee paarden, die met hun rug met elkaar verbonden zijn. Op deze manier kan men verschillende combinaties van elk twee paarden maken. Dit motief is stokoud en heeft zijn oorsprong in de zogenaamde Animal Style in Centraal Azië.

De hier beschreven objecten zijn een selectie uit een grotere collectie. Zoals $\mathrm{ik}$ al aangegeven heb, is de selectie een menging van kwaliteit en inhoud, wat altijd moeilijk is te verantwoorden. Ik kan eigenlijk alleen maar de wens uitspreken dat de komende tijd meer aandacht aan dit 'stiefkind' in de Aziatische kunst gegeven gaat worden: de Tibetaans-boeddhistische kunst heeft nog zo veel meer te bieden.

Sjoerd de Vries (1952) is kunsthistoricus en tibetoloog. Hij is de eigenaar van galerie Astamangala in Amsterdam, gespecialiseerd in oude kunst uit het Himalaya-gebied. Naast zijn werk als kunsthandelaar is hij ook wetenschappelijk actief. Ook is hij extern conservator in het Wereldmuseum te Rotterdam. 


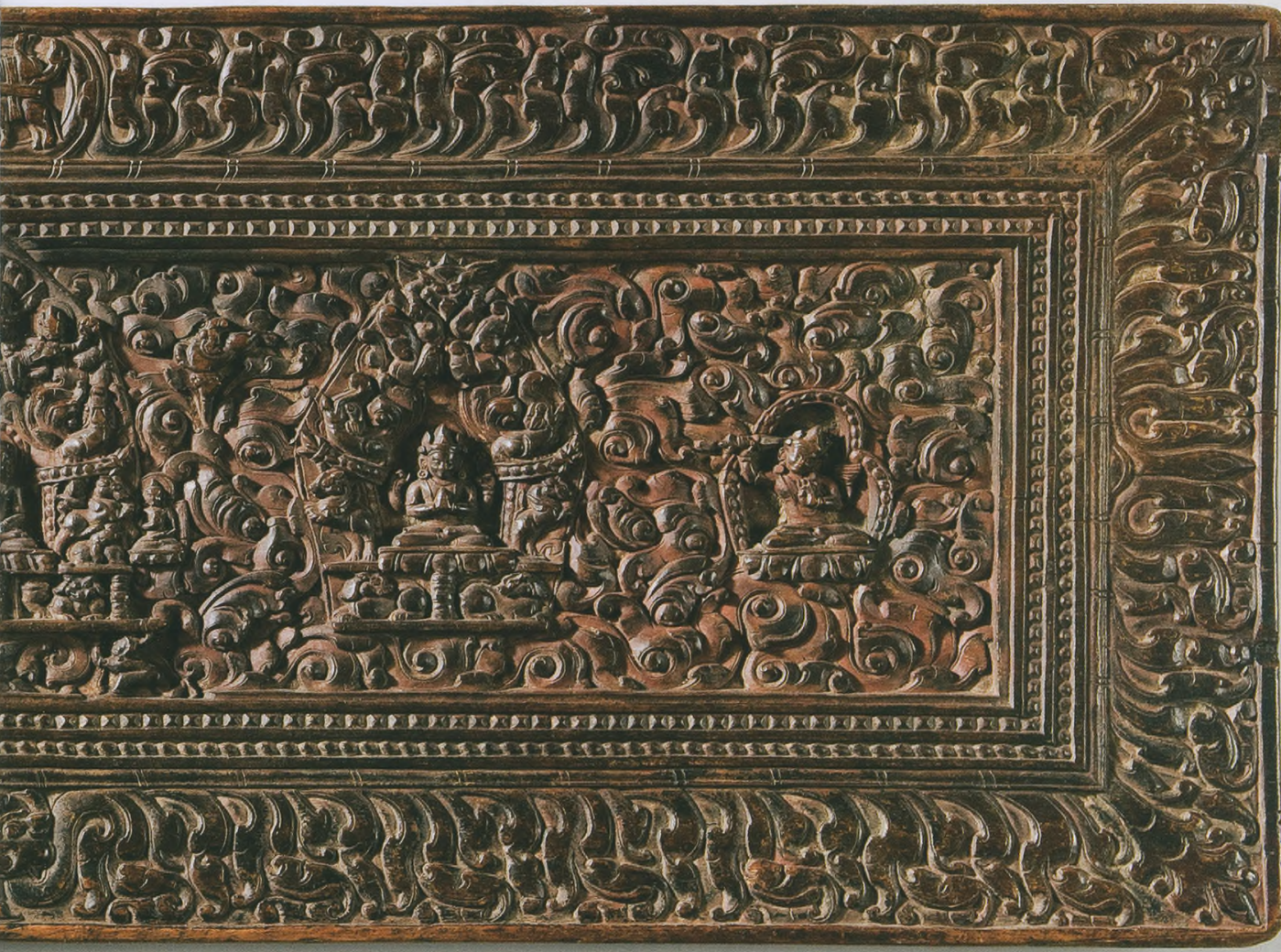

\section{Literatuur}

Siegbert Hummel, 'sMan-gyi-Bla', Bulletin of Tibetology, 2/2 (1965), nr. 2, pp. 9-15. Rob Linrothe (ed.), Holy Madness, Portraits of Tantric Siddhas, Serindia Publications,

Chicago, 2006. [tent.cat. in samenw. met Rubin Museum of Art, New York] Armand Neven, Lamaïstische kunst, Generale Bankmaatschappij, Brussel, 1975. [tent.cat.] Ulrich Von Schroeder, Empowered Masters: Tibetan Wall Paintings of Mahasiddhas at Gyantse, Serindia Publications, Chicago, 2006.

Sjoerd de Vries, 'The Development of the Prabhamandala in early Tibetan Art', in: John Ardussi en Henk Bleezer (eds.), Impressions of Bhutan and Tibetan Art: Tibetan Studies III, Brill, Leiden, 2002, pp. 125-33. [PIATS 2000: Tibetan Studies: Proceedings of the Ninth Seminar of the International Association for Tibetan Studies, Leiden 2000]

\section{Noten}

* Fotografie: Margareta Svensson

1 Hummel 1965: 9-15; Neven 1975: 31-2 (nr. 55-56).

2 Vertaald door Mevr. Feng Chun Ma (informatie van de eigenaar).

3 Linrothe 2006: 308-9; Von Schroeder 2006: 30-1.

4 De Vries 2002: 125-31. 
14

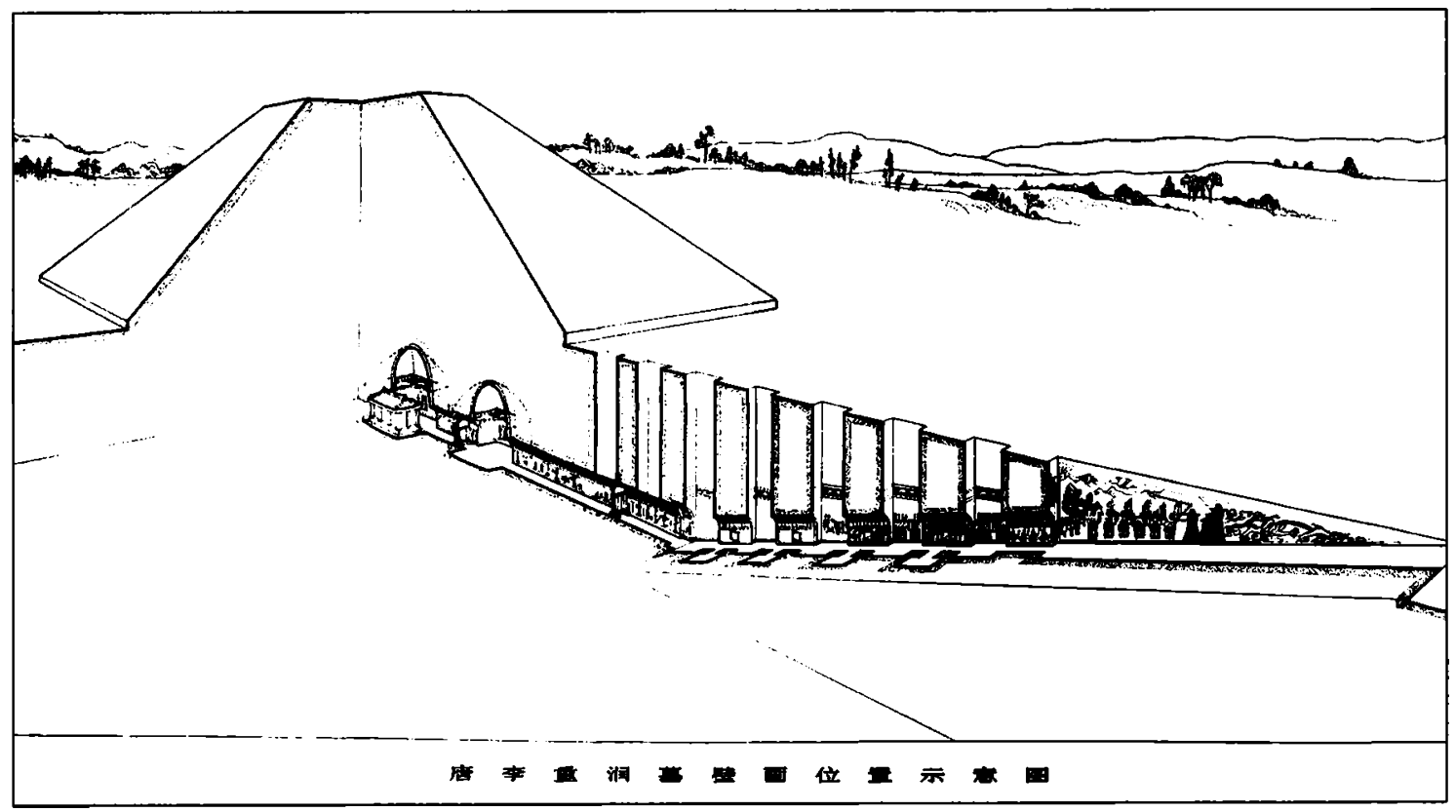

afb. 1

Doorsnede van de graftombe van prins Li Xian

(Li Zhongrun) overleden

in 701 en herbegraven

in de Qianling tombe

in 705. Let op de schuin

aflopende gang naar de

grafkamer met aan

weerszijde de nissen

waar graffiguren werden

gezet. (Van Valen 2005:

21).

Downloaded from Brill.com@4/26/2023 05:44:46AM

via free access 